\title{
Inhibitory effects of oil extract of green Acalypha (Acalypha wilkesiana) on antioxidant and neurotransmitter enzymes in Callosobruchus maculatus
}

\author{
Mercy O. Oni ${ }^{1}$, Olaniyi C. Ogungbite $2^{2^{*}} \mathbb{D}$, Samuel O. Oguntuase ${ }^{1}$, Olufemi S. Bamidele ${ }^{3}$ and Thomas I. Ofuya ${ }^{1}$
}

\begin{abstract}
Background: Callosobruchus maculatus is an important insect pest of cowpea. The inhibitory effects of oil extract of Acalypha wilkesiana (Muell Arg.) leaves on antioxidant, neurotransmitter, and detoxifying enzyme in adult Callosobruchus maculatus (Fabricius) were evaluated under laboratory condition. The leaves of the plant were collected fresh and air-dried before the oil was extracted from them through cold extraction method while ethanol was used as solvent. Adult C. maculatus were exposed to $0.2,0.4,0.6,0.8$, and $1.0 \mathrm{ml}$ of $0.5 \%$ concentration of the oil extract and were homogenized separately. The supernatants gotten from them were used as enzyme sources. The activities of SOD, CAT, GPx, AChE, CarEST and GST were observed with photospectrometer. GC-MS analysis was done to evaluate the active compounds present in the oil extract.

Results: The activities of the enzymes increased at lower dosages of the oil extract $(0.2$ and $0.4 \mathrm{ml})$ and reduced drastically at higher dosages of the oil $(0.6,0.8$, and $1.0 \mathrm{ml})$. However, AChE activity was more affected by the oil extract as it was almost inhibited by the oil extract. The GC-MS showed that 114 compounds were present in the oil extract of the plant while acetaldehyde had the highest percentage (46.07\%) of the total compounds.

Conclusion: Based on these findings, the oil extract of A. wilkesiana could be a good biopesticide for the control of adult C. maculatus instead of synthetic chemical insecticides.
\end{abstract}

Keywords: Plant extract, Acalypha wilkesiana, Callosobruchus maculatus, Antioxidant, Detoxification, Enzymes

\section{Background}

Callosobruchus maculatus is an important insect pest of cowpea, Vigna unguiculata (Walp). The insect is a cosmopolitan insect with ability to infest both on the field and in storage where its destructive activities multiply. Researches have shown that the insect is capable of causing more than $65 \%$ destruction of cowpea grains in storage and if left on unchecked it may cause total wastage of cowpea within 6 months of storage (Abd-Elhady, 2012; Ashamo, Odeyemi, \& Ogungbite, 2013; Kedia, Prakash, Mishra, Singh, \& Dubey, 2013; Oni, 2014; Shimomura et al., 2010). The ability of the insect to have

\footnotetext{
* Correspondence: olaniyizoguns@gmail.com

${ }^{2}$ Department of Biology, Federal University of Technology Akure, Akure, Nigeria

Full list of author information is available at the end of the article
}

many generations within a year makes its infestation on cowpea to be more pronounced (Kedia et al., 2013; Ogungbite, 2015; Oni, Ogungbite, \& Ofuya, 2018).

Considering the importance of cowpea as main source of protein in the diet of families that cannot afford animal proteins, researchers have been combating the insect and other stored product insect pests with the use of synthetic chemical insecticides which were discovered in the late 1930s (Begum, Shaarma, \& Pandey, 2013; Forim, Da-silva, \& Fernandes, 2012; Isman, 2000, 2006). In recent decades, the adverse effects of many of these synthetic chemical insecticides both on human and environmental health called for their outright replacement with insecticides that have no or little adverse effects on humans and their habitat (Jaya, Prakash, \& Dubey, 2012; 
Scott et al., 2003; Sivakumar, Chandrasekaran, Vijayaraghavan, \& Selvaraj, 2010; Tripathi \& Dubey, 2004).

Plant extracts and powders have for ages been the major weapons used by farmers against insect pests even before the discovery of synthetic chemical insecticides because they are believed to contain myriads of phytochemicals that are insecticidal in nature (Goławska \& Łukasik, 2012; Goławska, Łukasik, Goławski, Kapusta, \& Janda, 2010; Zibaee, 2011). Thousands of researches have been done on botanical base insecticides, thus many plant species have proven insecticidal and there are many publications on them. In spite of these many publications on botanical insecticides, Isman and Grieneisen (2014) opined that only few information are derivable from them because many of them failed to address the mode of actions of the plant base insecticides. Martins, Freire, Parra, and Macedo (2012), Rattan and Sharma (2011), and Zibaee and Bandani (2010) suggested that once the insecticidal potential of a botanical has been discovered, its effects on antioxidant, digestive, and detoxifying enzymes in insects should be evaluated and active compounds present in it should be determined as this will ensure the protection of non-target organisms.

Acalypha wilkesiana (Muell Arg.) green acalypha is a medicinal plant whose insecticidal potential of its extract had been proven (Oguntuase, 2018) but much work have not been done as regard its mode of action and active compounds present in it. This present work evaluated the inhibitory effects of $A$. wilkesiana oil extract on the antioxidant, detoxifying, and neurotransmitter enzymes in Callosobruchus maculatus and as well determined the active compounds present in it.

\section{Materials and methods}

\section{Insect culture}

The initial culture of $C$. maculatus used was collected from already infested cowpea grains in the Entomology Laboratory of the Department of Crop, Soil and Pest Management, Federal University of Technology, Akure. The insects were sub-cultured on clean uninfested IfeBrown cowpea variety inside a plastic container at laboratory temperature of $28 \pm 2{ }^{\circ} \mathrm{C}$ and relative humidity of $75 \pm 5 \%$. The cover of the container was perforated and covered with muslin cloth to allow aeration and prevent the escape of the insect and entry of other insects that may be a parasitoid to the beetle (Ashamo et al., 2013).

\section{Collection of plant material and extraction}

The leaves of A. wilkesiana used were obtained from an open field inside the campus of Federal University of Technology Akure and were air-dried under shade before being pulverized into fine powder with Electric blender. The powder of the leaves was kept inside an air-tight plastic container and was kept till further use. The oil from the powder was extracted using cold extraction method while ethanol was used as solvent. The plant powder $(500 \mathrm{~g})$ was soaked in $1 \mathrm{l}$ of ethanol for 4 days and the mixture was stirred vigorously to ensure even mixture. The oil extract was separated from the chaff of the powder with muslin cloth while the oil extract was separated from the solvent using rotary evaporator. The oil extract was kept inside air-tight container and placed inside refrigerator for subsequent use. From the main stock of the oil extract, $0.5 \%$ concentration of the oil extract was made and $0.2,0.4,0.6,0.8$, and $1 \mathrm{ml}$ dosages were separately made from it.

\section{Bioassay}

Filter papers placed inside Petri-dishes were treated with $0.2,0.4,0.6,0.8$, and $1 \mathrm{ml}$ dosages of $0.5 \%$ concentration of $A$. wilkesiana oil extract in five replicates. Two hundred fifty unsexed 0-24 old C. maculatus were placed in each of the Petri-dish and were left for $24 \mathrm{~h}$. After $24 \mathrm{~h}$, the live and dead C. maculatus were separated. The live insects were quickly demobilized by freezing and the wings were removed while the remaining body parts were homogenized in ice-cold buffer $(25 \mathrm{mM}$ potassium phosphate buffer, $\mathrm{pH} \quad 7.2$ EDTA, and $1 \mathrm{mM} 2$ mercaptoethanol). The homogenates were centrifuged at $10,000 \mathrm{~g}$ for $10 \mathrm{~min}$ at $4{ }^{\circ} \mathrm{C}$ (Bamidele, Ajele, Kolawole, \& Akinkuolere, 2013). The floating lipids were carefully filtrated from the supernatants through funnel plugged with glass wool and the supernatants were kept in aliquots at temperature below $-4{ }^{\circ} \mathrm{C}$ for subsequent use.

\section{Enzyme assays}

\section{Determination of catalase activity}

Catalase, EC. 1.11.1.6 activity was assayed according to the method of Aebi (1984) by mixing $2.4 \mathrm{ml}$ phosphate buffer (50 mM, pH 7.0), $10 \mu \mathrm{l}$ of $19 \mathrm{mM} \mathrm{H}_{2} \mathrm{O}_{2}$ and $50 \mu \mathrm{l}$ enzyme source (supernatant). The decrease in absorbance was measured at $240 \mathrm{~nm}$ over a 3 -min period at $25{ }^{\circ} \mathrm{C}$ against the blank on a spectrophotometer. Two readings were taking at 0 and $3 \mathrm{~min}$. Catalase (CAT) activity was calculated with the equation below:

$$
\mathrm{CAT}=\frac{R_{1}-R_{2}}{T}
$$

Where $R_{1}$ is the initial reading at $0 \mathrm{~min}, R_{2}$ is the final reading after $3 \mathrm{~min}$, and the $T$ is the time intervals.

\section{Determination of superoxide dismutase activity}

Superoxide dismutase (SOD) was assayed according to Beauchamp and Fridovich (1971) as described by Bamidele et al. (2013). The reaction mixture contained $1.17 \mu \mathrm{M}$ riboflavin, $0.1 \mathrm{M}$ methione, $0.2 \mu \mathrm{M}$ potassium 
cyanide $(\mathrm{KCN})$, and $0.56 \mu \mathrm{M}$ nitro blue tetrazolium salt (NBT) dissolved in $3 \mathrm{ml}$ of $50 \mathrm{mM}$ sodium phosphate buffer ( $\mathrm{pH}$ 7.8). Three milliliter of the reaction medium was mixed with $1 \mathrm{ml}$ of enzyme (supernatant) and the mixtures were illuminated in glass test tubes by two sets of Philips $40 \mathrm{~W}$ fluorescent tubes in a single row. Reaction was initiated at $30{ }^{\circ} \mathrm{C}$ for $1 \mathrm{~h}$ by the illumination. Identical solutions that were kept under dark served as blanks while absorbance was read at $560 \mathrm{~nm}$ in the spectrophotometer against the blank. SOD activity was expressed in units ( $\mathrm{U} \mathrm{mg}^{-1}$ protein). One unit is defined as the amount of change in the absorbance by $0.1 \mathrm{~h}^{-1} \mathrm{mg}^{-1}$ protein. SOD activity was calculated with the equation below:

$$
\begin{aligned}
& \mathrm{SOD}=R_{4} / \mathrm{A} \\
& \mathrm{A}=R_{1}(50 / 100) \\
& R_{4}=R_{3}-R_{2} \\
& R_{3}=\mathrm{OD} \text { of sample } \\
& R_{2}=\mathrm{OD} \text { of blank } \\
& R_{1}=\text { OD of reference }
\end{aligned}
$$

Where $R_{1}$ is the absorbance of the reference solution, $R_{2}$ is the absorbance of the blank, and $R_{3}$ is the absorbance of sample when enzyme has been added at a particular level.

\section{Determination of glutathione peroxidase activity}

The GPX, EC 1.11.1.9 activity was assayed with $\mathrm{H}_{2} \mathrm{O}_{2}$ as substrate according to the method of Paglia and Valentine (1967) as described by Bamidele et al. (2013). The reaction was monitored indirectly as the oxidation rate of NADPH at $340 \mathrm{~nm}$ for $3 \mathrm{~min}$. Enzyme activity was expressed as micromoles of NADPH consumed per minute per milligram of protein, using an extinction coefficient of $6.220 \mathrm{M}^{-1} \mathrm{~cm}^{-1}$. A blank without enzyme was used as a control for the non-enzymatic oxidation of NADPH upon addition of $\mathrm{H}_{2} \mathrm{O}_{2}$ in $0.1 \mathrm{M}$ Tris buffer, $\mathrm{pH}$ 8.0. Glutathione peroxidase (GPx) activity was calculated with the equation below:

$$
\mathrm{GPX}=\frac{2\left(\mathrm{mRate}_{\mathrm{s}}-\mathrm{mRate}_{\mathrm{b}}\right) \times V_{\mathrm{Rxm}}}{6.22 \times V_{\mathrm{s}}} \times \frac{\mathrm{df}}{1}
$$

Where mRate $_{\mathrm{s}}=-1000 \times \Delta \mathrm{A}_{340} / \mathrm{min}$ of sample mRate $_{\mathrm{b}}=-1000 \times \Delta \mathrm{A}_{340} / \mathrm{min}$ of blank

$6.22=\mathrm{NADPH} 340 \mathrm{~nm}$ millimolar absorption coefficient at $1 \mathrm{~cm}$ path length

$V_{\mathrm{Rxm}}=$ Volume of reaction mixture

$V_{\mathrm{s}}=$ Volume of sample

2 = correction for 2 mol GSH oxidized to 1 mol GSSG per mole NADPH

$\mathrm{df}=$ Sample dilution factor

\section{Determination of AChE activity}

The acetylcholine esterase (AChE) activity was determined by the method described by Ellman, Courtney, Andres, and Featherstone (1961) as described by Bocquene and Galgani (1998). Supernatants were used as enzymes while using acetylthiocholine iodide (ATCL) at $0.25 \mathrm{nM}$ as substrate. Aliquots of enzyme $(100 \mu \mathrm{l})$ and DTNB $(100 \mu \mathrm{l}$ of $0.01 \mathrm{M})$ were added to $0.1 \mathrm{M}$ phosphate buffer $(\mathrm{pH} 7.4 ; 600 \mu \mathrm{l})$ then $100 \mu \mathrm{l}$ phenylpropene test solutions prepared in absolute ethanol were added to the mixture. Control experiment was prepared by addition of $100 \mu \mathrm{l}$ absolute ethanol. The mixtures were incubated at $35{ }^{\circ} \mathrm{C}$ for $15 \mathrm{~min}$ and $100 \mu \mathrm{l} \mathrm{ACTL}$ was added to start the reaction. Absorbance was measured at $412 \mathrm{~nm}$ using photo-spectrometer. The percentage $\mathrm{AChE}$ inhibition was calculated with the equation below

$\mathrm{AChE}$ activity $=\frac{\Delta A_{412} \times \operatorname{Vol}_{T} \times 1000}{1.36 \times 10^{4} \times \text { ligthpath } \times V l_{s} \times[\text { protein }]}$

Where $\Delta \mathrm{A}_{412}=$ change in absorbance $(\mathrm{OD})$ per min, corrected for spontaneous hydrolysis

$\mathrm{Vol}_{\mathrm{T}}=$ total assay volume $(0.380 \mathrm{ml})$

$1.36 \times 10^{4}=$ extinction coefficient of TNB $\left(\mathrm{M}^{-1} \mathrm{~cm}^{-1}\right)$

Lightpath $=$ microplate well depth $(1 \mathrm{~cm})$

$\mathrm{Vol}_{\mathrm{S}}=$ sample volume (in $\mathrm{ml}$ )

[protein] = concentration of protein in the enzymatic extract $\left(\mathrm{mg} \mathrm{ml}^{-1}\right)$

\section{Determination of carboxylesterase activity}

The activity of carboxylesterase was determined according to Van Asperen (1962). Undiluted $100 \mu \mathrm{l}$ of the homogenates and diluted $100 \mu \mathrm{l}$ of the homogenates were briefly incubated with $1 \mathrm{ml}$ of sodium phosphate buffer (20 mM, pH 7.0) containing $250 \mu \mathrm{M}$ of naphthyl acetate for $30 \mathrm{~min}$ at $28{ }^{\circ} \mathrm{C}$. Then, $400 \mu \mathrm{l}$ of freshly prepared $0.3 \%$ fast blue B in $3.3 \%$ SDS were added to stop the enzymatic reaction and the color was allowed to develop for $15 \mathrm{~min}$ at $28{ }^{\circ} \mathrm{C}$. The optical density of the sample was read at $430 \mathrm{~nm}$ against the reagent blank in Shimadzu UV-160A spectrophotometer.

\section{Determination of glutathione transferase activity}

Glutathione transferase (GST) catalytic activity was determined spectrophotometrically using Biochrome-4060 model spectrophotometer with the aromatic substrate, 1-chloro-2,4 dinitobenzene (CDNB) by monitoring the change in absorbance, due to thioether formation at $340 \mathrm{~nm}$ and $25{ }^{\circ} \mathrm{C}$ as described by Habig, Pabst, and Jokoby (1974). The assay mixture contained in a total volume of $1 \mathrm{ml}$ which comprised $0.1 \mathrm{M}$ potassium phosphate buffer at $\mathrm{pH}$ 7.4, $1 \mathrm{mM}$ CDNB in ethanol, $1 \mathrm{mM}$ GSH, and the enzyme solution. The absorbance at $340 \mathrm{~nm}$ of the complete assay mixture was monitored 
against a control containing buffer instead of the enzyme and treated similarly. The product extinction coefficient was taken to be $9.6 \mathrm{mM}^{-1}$ and defined as the amount of enzyme which catalyzed the formation of $1 \mu \mathrm{mol} / \mathrm{min} /$ $\mathrm{mg}$ protein. Protein concentration was determined by the method of Bradford (1976) using bovine serum albumin (BSA) as a standard. GST activity was calculated with the equation below:

GST activity $=\frac{\Delta \mathrm{OD}_{340 \mathrm{~nm}} / \min \times 100 \mu \mathrm{l}}{2.99 \mathrm{mM}^{-1} \times 10 \mu \mathrm{l}} \times \frac{\text { Sample dilution }}{1}$

Evaluation of the active compounds present in the leaves oil extract of $A$. wilkesiana

The aliquot used for the GC-MS qualitative characterization analysis was prepared by dissolving the oil extract of $A$. wilkesiana in $5 \mathrm{ml}$ ethanol. The mixture was then separated for clear solvent layer by centrifuging at $4000 \mathrm{rpm}$. A qualitative characterization analysis of possible compounds present in the oil extract was carried out using GC-MS using scan mode. This analysis was performed using 7820A gas chromatograph coupled to $5975 \mathrm{C}$ inert mass spectrometer (with triple axis detector) with electron-impact source (Agilent Technologies). The stationary phase of separation of the compounds was HP-5 capillary column coated with $5 \%$ phenyl methyl siloxane ( $30 \mathrm{~m}$ length $\times 0.32 \mathrm{~mm}$ diameter $\times 0.25 \mu \mathrm{m}$ film thickness) (Agilent Technologies). The carrier gas was Helium used at constant flow of $1.6 \mathrm{ml} / \mathrm{min}$ at an initial nominal pressure of $2.84 \mathrm{psi}$ and average velocity of $46 \mathrm{~cm} / \mathrm{s}$. One microliter of the samples was injected in splitless mode at an injection temperature of $260{ }^{\circ} \mathrm{C}$. Purge flow was $21.5 \mathrm{ml} / \mathrm{min}$ at $0.50 \mathrm{~min}$ with a total flow of $25.8 \mathrm{ml} / \mathrm{min}$; gas saver mode was switched on. Oven was initially programmed at $60{ }^{\circ} \mathrm{C}(1 \mathrm{~min})$ then ramped at $4{ }^{\circ} \mathrm{C} / \mathrm{min}$ to $110{ }^{\circ} \mathrm{C}$ (3 min) then $8{ }^{\circ} \mathrm{C} / \mathrm{min}$ to $260{ }^{\circ} \mathrm{C}(5 \mathrm{~min})$ and $10{ }^{\circ} \mathrm{C} / \mathrm{min}$ to $300{ }^{\circ} \mathrm{C}(12 \mathrm{~min})$. Run time was $56.25 \mathrm{~min}$ with a 3 min solvent delay. The mass spectrometer was operated in electron-impact ionization mode at $70 \mathrm{eV}$ with ion source temperature of $230{ }^{\circ} \mathrm{C}$, quadrupole temperature of $150{ }^{\circ} \mathrm{C}$, and transfer line temperature of $280{ }^{\circ} \mathrm{C}$. Scanning of possible alkaloid compounds was from $\mathrm{m} / \mathrm{z} 30$ to $550 \mathrm{amu}$ at $2.62 \mathrm{~s} / \mathrm{scan}$ rate and was identified by comparing measured mass spectral data with those in NIST 14 Mass Spectral Library and literature.

\section{Bioassay and statistical analysis}

All the data obtained in this work were subjected to one-way analysis of variance and means were separated with Tukey honestly significant test. SPSS Version 21 was used for the analysis.

\section{Results}

Effects of oil extract of $A$. wilkesiana on the activities of antioxidant enzymes in $C$. maculatus

The effects of $A$. wilkesiana oil extract on the activities of SOD, CAT, and GPx were presented in Fig. 1. The effects of the oil extract were directly proportional to the dosage of the oil extract. Statistically significant differences existed between the treatments at $F_{5,24}=207.233$, $p<0.0001$ (SOD), $F_{5,24}=106.932, p<0.0001$ (CAT), and $F_{5,24}=1492.329, p<0.0001$ (GPx). Tukey multiple comparison showed that for the SOD, significant difference did not existed between $0.2 \mathrm{ml}$ of the oil extract and $0.8 \mathrm{ml}$ and between $0.2 \mathrm{ml}$ of the extract and control at $p=0.239$ and 0.529 respectively. Also, there were no significant differences that existed between $0.4 \mathrm{ml}$ and $0.8 \mathrm{ml}$ of the extract at $p=0.165$. For CAT, no significant difference existed between $0.2 \mathrm{ml}$ and $0.6 \mathrm{ml}$ of the oil extract as well as between $0.2 \mathrm{ml}$ and the control at $p=$ 0.07 and $p=0.612$. Tukey multiple comparison showed that for the GPx, significant differences existed between all the treatments. The highest SOD activity was recorded at $0.3 \mathrm{ml}(14.64 \mu \mathrm{mol} / \mathrm{min} / \mathrm{ml})$ of the extract while the lowest activity of $3.71 \mu \mathrm{mol} / \mathrm{min} / \mathrm{ml}$ was recorded at $1.0 \mathrm{ml}$ dosage of the oil extract and they were significantly $(p<0.05)$ different from all other treatments. The lowest CAT activity $(2.74 \mu \mathrm{mol} / \mathrm{min} / \mathrm{ml})$ was recorded at $1.0 \mathrm{ml}$ of the oil extract while the highest activity $(5.79 \mu \mathrm{mol} / \mathrm{min} / \mathrm{ml})$ was recorded at $0.4 \mathrm{ml}$ of the extract and was significantly different from others. At $0.4 \mathrm{ml}$, the highest activity of GPx $(52.58 \mu \mathrm{mol} / \mathrm{min} / \mathrm{ml})$ was recorded while the lowest activity $(20.06 \mu \mathrm{mol} / \mathrm{min} /$ $\mathrm{ml}$ ) of the enzyme was recorded at $1.0 \mathrm{ml}$ of the oil extract. Generally, the activities of the three enzymes increased above that of the control treatment with increase in dosage of the oil extract but drastically reduced at higher dosages $(0.8$ and $1.0 \mathrm{ml})$.

\section{Effects of $A$. wilkesiana oil extract on activities of AChE and CarEST}

Figure 2 showed the effects of $A$. wilkesiana oil extract at different dosages on activities of AChE and carboxylesterase (CarEST). The activities of the enzymes varied with the dosages of the oil extract. Statistically significant variations existed between the treatments at $F_{5,24}=2800.047$, $p<0.0001$ (AChE) and $F_{5}, \quad 24=932.222, \quad p<0.0001$ (CarEST). Tukey multiple comparison showed that for $\mathrm{AChE}$, significant differences existed between all the treatments while for CarEST significant difference did not existed between $0.2 \mathrm{ml}$ of the oil extract and the control at $p=0.223$. The activities of AChE decreased with increase in the dosage of the oil extract. The highest AChE activity was recorded in the control $(0.41 \mu \mathrm{mol} / \mathrm{min} / \mathrm{ml})$ while the activity of the enzyme is almost inhibited as only $0.0012 \mu \mathrm{mol} / \mathrm{min} / \mathrm{ml}$ activity of the enzyme was recorded 


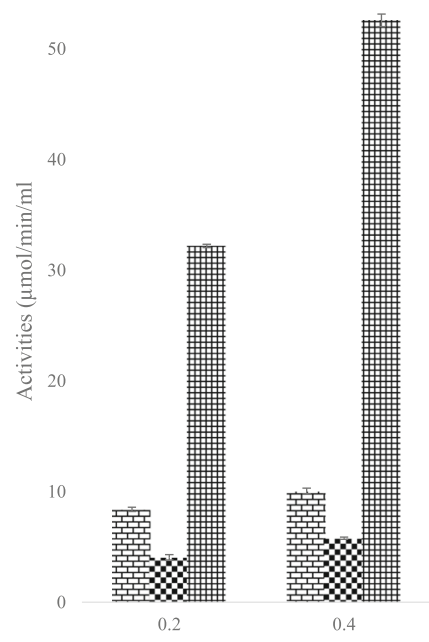

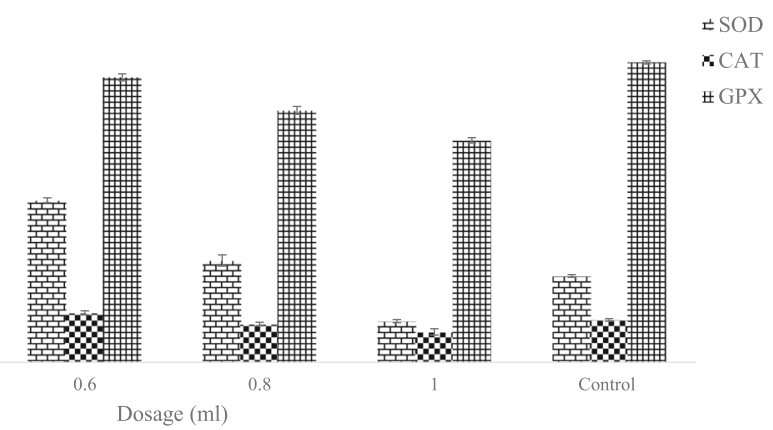

Fig. 1 Effect of oil extract of A. wilkesiana on the activities of antioxidant enzymes

and was significantly $(p<0.05)$ different. The activities of the CarEST increased with increase in the dosage of the oil extract but drastically reduced at higher dosages $(0.8$ and $1.0 \mathrm{ml})$. The highest activity $(1.62 \mu \mathrm{mol} / \mathrm{min} / \mathrm{ml})$ of the enzyme was recorded at $0.4 \mathrm{ml}$ of the oil extract while the lowest activity $(0.62 \mu \mathrm{mol} / \mathrm{min} / \mathrm{ml})$ was recorded at $1.0 \mathrm{ml}$ dosage and was significantly $(p<0.05)$ different from other dosages.

Effects of $A$. wilkesiana oil extract on the activities of GST The effects of $A$. wilkesiana oil extract at different dosages on the activities of GST are presented in Fig. 3. The activity of the enzyme is dependent on the dosages of the oil extract. Significant statistical difference existed between the treatments at $F_{5,24}=2800.047, p<0.0001$. Tukey multiple comparison showed that significant differences existed between the treatments except between 0.8 and $1.0 \mathrm{ml}$ of the oil extract except at $p=0.088$. The highest GST activity of $83.55 \mu \mathrm{mol} / \mathrm{min} / \mathrm{ml}$ was recorded at $0.4 \mathrm{ml}$ of $A$. wilkesiana oil extract while the lowest activity of the enzyme $(38.15 \mu \mathrm{mol} / \mathrm{min} / \mathrm{ml})$ was recorded at $1.0 \mathrm{ml}$ of the oil extract.

\section{Active compound present in the leaves oil extract of $A$. wilkesiana}

The active compounds present in the leaves oil extract of A. wilkesiana is presented in Table 1 . One hundred fourteen active compounds were present in the oil

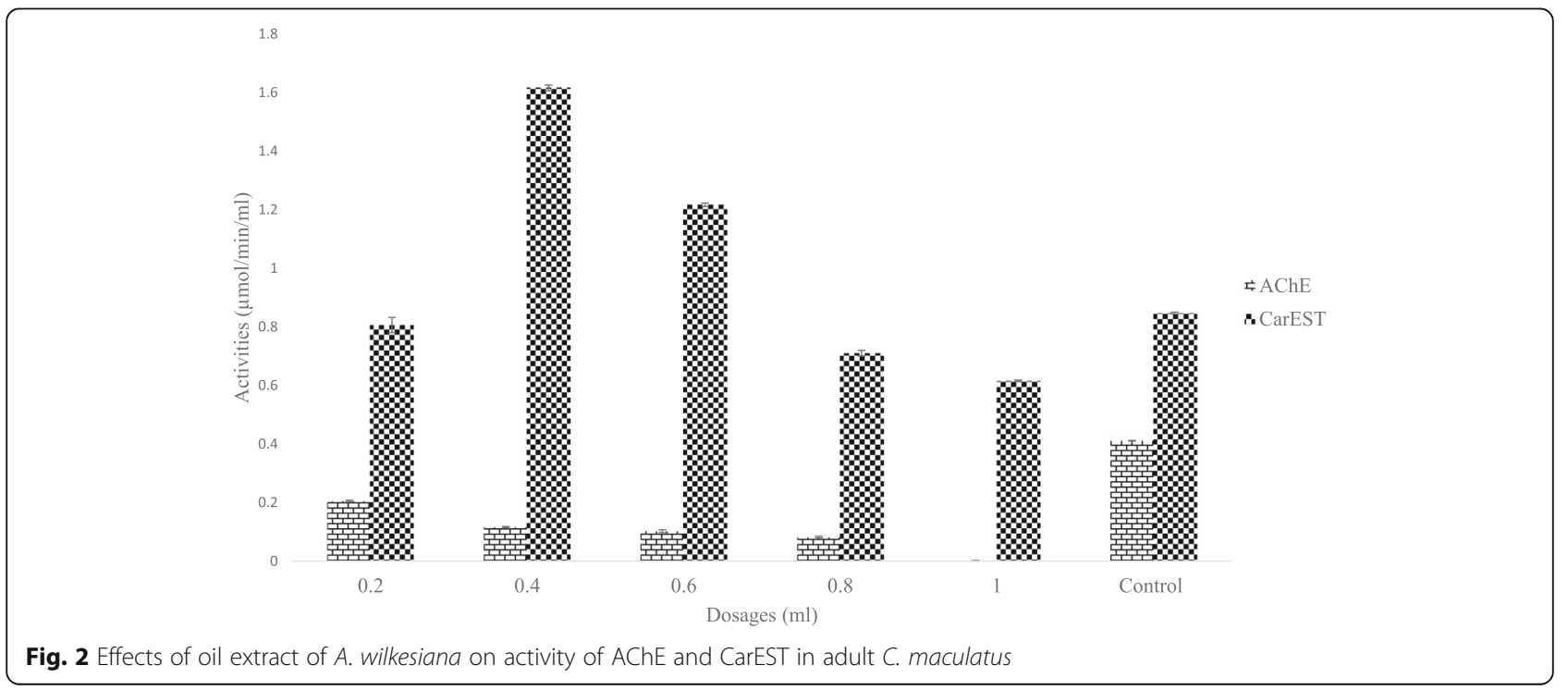




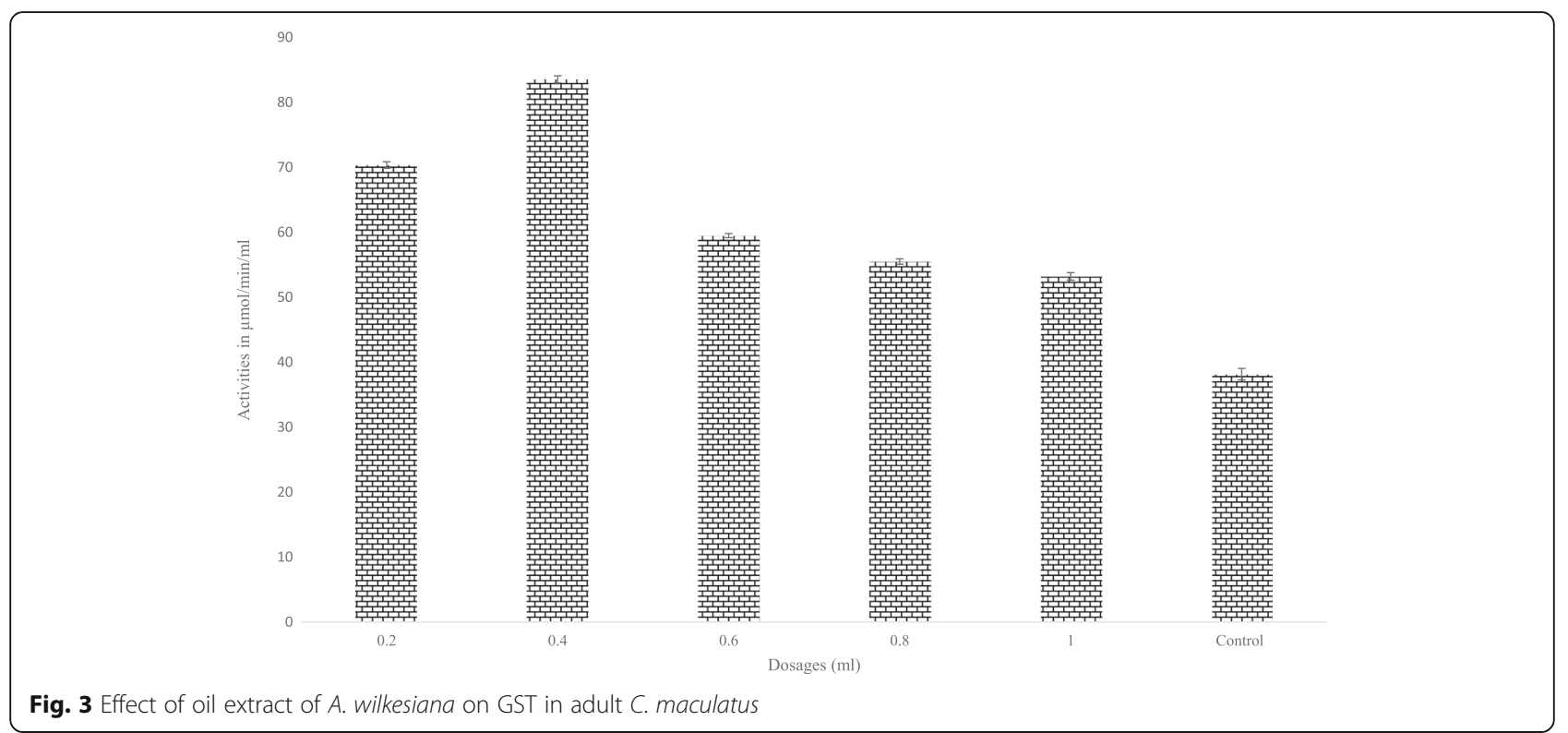

extract of the plant. Acetaldehyde, Bicyclo[3.1.1]heptane, 2,6,6-trimethyl-[1R-(1.alpha.,2.beta.,5.alpha.)]-, 3-Buten2-one, 4-(6,6-dimethyl-1-cyclohexen-1-yl)-, and cyclopropyl carbinol are the five major compounds with $46.07,3.23,2.93,2.85$, and $2.72 \%$ respectively. The molecular structure and mass of the first five compounds with higher percentage in the oil extract were presented in Fig. $4 a-e$ respectively.

\section{Discussion}

Inhibition of enzymes activities is a well-known instrument to block numbers of important biochemical and physiological processes leading to discovery of new metabolic pathways and in-depth knowledge of many kinetic mechanisms of enzyme-controlled reactions (Guerrero \& Rosell, 2005). Thus, the development of potent enzyme inhibitors is now an important field of research in biopesticides and pharmaceutical researchers. In spite of many publications on botanical oil extracts and powders by stored product entomologists and other related scientists, only few numbers of the publications provided adequate information that could help in the formulation, commercialization, and acceptability of botanical base insecticides (Isman \& Grieneisen, 2014). A. wilkesiana leaves oil extract being proven insecticidal by Oguntuase (2018) has not been evaluated for its inhibitory effects on different enzymes in adult $C$. maculatus. Thus, this work evaluated the inhibitory effect of oil extract of the plant on different enzymes in C. maculatus and as well evaluated the active compounds present in the oil extract.

The result of this work showed that the activity of the antioxidant, neurotransmitter, and detoxifying enzymes in adult $C$. maculatus varied with the dosages of the oil extract of A. wilkesiana. SOD is the first line of defense against toxic substance in insects, thus it prevents accumulation of oxygen free radicals (Kolawole, Olajuyigbe, Ajele, \& Adedire, 2014). The dismutation ability of the enzyme enables it to remove superoxide radicals $\left(\mathrm{O}_{2}{ }^{-}\right)$ to oxygen and hydrogen peroxide $\left(\mathrm{H}_{2} \mathrm{O}_{2}\right)$ (Henry, ChaoLin, Wen-Hui, Chia-Hsien, \& Hong-Zin, 2006; Olawale, Ikechukwu, Grace, \& Chidiebere, 2008). The variations in the activity of SOD at different dosages of $A$. wilkesiana revealed that the oil extract had induced some level of toxicity to the enzyme. Reactive oxygen species (ROS) are the contributors of oxidative stress that cause different diseases and disorders in insects (Buyukguzel, 2006). John, Kale, Rathore, and Bhatnagar (2001) reported that increase in SOD activity is an indicator for increase in ROS accumulation in insects. The overproduction of ROS leads to inability of the cell endogenous systems to neutralize them causing damage to proteins, lipids, mitochondria, and DNA of insects (Ali, 2012; Kolawole et al., 2014; Sankar, Telang, \& Manimaran, 2012). Therefore, the decrease in the activity of SOD at higher dosage of oil extract of $A$. wilkesiana leaves implied that more ROS had accumulated in the cell of the insect due to inability of the enzyme to scavenge them. The decrease in the activity of SOD at higher dosages of the oil extract showed that $\mathrm{O}_{2}{ }^{-}$and $\mathrm{H}_{2} \mathrm{O}_{2}$ had accumulated in the cell of the insect causing some levels of oxidative damages to the oil extract-stressed C. maculatus (Abdul Jaleel, Lakshmanan, Gomathinayagam, \& Panneerselvam, 2008) . Wang, Wen, Chang, and Duan (2002) opined that scavenging ability of SOD is temporary and limited. Thus, this supported the reason why the activity of the enzyme increased with increase in the dosage of the oil extract and drastically decreased with further increase in dosage 
Table 1 Active compounds present in the leaves oil extract of A. wilkesiana using GC-MS analysis

\begin{tabular}{|c|c|c|c|c|}
\hline SN & Retention time (min) & Compound name/hit name & $\begin{array}{l}\text { Quality ion (relative } \\
\text { intensity, \%) }\end{array}$ & $\begin{array}{l}\text { Percentage } \\
\text { total of all } \\
\text { compound (\% total) }\end{array}$ \\
\hline 1 & 7.135 & Acetaldehyde & 83 & 46.0737 \\
\hline 2 & 25.766 & $\begin{array}{l}\text { Bicyclo[3.1.1]heptane, 2,6,6-trimethyl-, } \\
\text { [1R-(1.alpha.,2.beta.5.alpha.)]- }\end{array}$ & 50 & 3.2297 \\
\hline 3 & 24.318 & 3-Buten-2-one, 4-(6,6-dimethyl-1-cyclohexen-1-yl)- & 27 & 2.9320 \\
\hline 4 & 16.168 & Cyclopropyl carbinol & 53 & 2.8494 \\
\hline 5 & 23.944 & 1,2-Hydrazinedicarboxaldehyde & 47 & 2.7183 \\
\hline 6 & 24.217 & 1-Undecanol & 22 & 2.6824 \\
\hline 7 & 24.686 & 4-Hydroxy-4-(4,6-dimethylcyclohex-3-enyl)butan-2-one & 16 & 1.6914 \\
\hline 8 & 5.580 & Erythritol & 80 & 1.6601 \\
\hline 9 & 44.331 & Testosterone cypionate & 55 & 1.6126 \\
\hline 10 & 21.041 & p-Dioxane, methylene- & 27 & 1.2305 \\
\hline 11 & 23.024 & 4-Camphenylbutan-2-one & 25 & 1.2291 \\
\hline 12 & 25.131 & Bicyclo[3.3.0]octan-2-one, 7-ethylidene- & 50 & 1.2094 \\
\hline 13 & 27.796 & Hexadecanoic acid, ethyl ester & 98 & 1.1615 \\
\hline 14 & 18.970 & 3,4-Furandiol, tetrahydro-, trans- & 59 & 1.1195 \\
\hline 15 & 26.104 & 1-Methyl-4-[nitromethyl]-4-piperidinol & 38 & 1.0566 \\
\hline 16 & 17.973 & Methanimidamide, $N^{\prime}$-(2-cyanophenyl)-N,N-dimethyl- & 53 & 0.8264 \\
\hline 17 & 25.665 & Propylamine, 3-(furan-2-yl)-1-methyl- & 47 & 0.7989 \\
\hline 18 & 23.350 & Phenylephrine & 47 & 0.7775 \\
\hline 19 & 22.941 & 1,6-Octadiene, 3-ethoxy-3,7-dimethyl- & 35 & 0.7611 \\
\hline 20 & 24.478 & $\begin{array}{l}\text { Cyclohexanol, 2-methyl-3-(1-methylethenyl)-, acetate, } \\
\text { (1.alpha.,2.alpha.,3.alpha.)- }\end{array}$ & 52 & 0.7111 \\
\hline 21 & 42.978 & Acetamide, 2-(adamantan-1-yl)-N-(1-adamantan-1-ylethyl)- & 30 & 0.7016 \\
\hline 22 & 22.822 & Benzyl alcohol, p-hydroxy-.alpha.-[(methylamino)methyl]- & 50 & 0.6889 \\
\hline 23 & 29.808 & (E)-9-Octadecenoic acid ethyl ester & 91 & 0.6631 \\
\hline 24 & 27.487 & n-Hexadecanoic acid & 97 & 0.6578 \\
\hline 25 & 35.025 & 3-Methyl-3,5-(cyanoethyl)tetrahydro-4-thiopyranone & 40 & 0.6284 \\
\hline 26 & 43.453 & 3,6-Bis-dimethylaminomethyl-2,7-dihydroxy-fluoren-9-one & 1 & 0.6237 \\
\hline 27 & 20.282 & 1,2-Ethanediol, 1-(2-phenyl-1,3,2-dioxaborolan-4-yl)-, [S-( $\left.\left(\mathrm{R}^{*}, \mathrm{R}^{*}\right)\right]$ - & 72 & 0.6152 \\
\hline 28 & 13.990 & Glutaraldehyde & 45 & 0.6055 \\
\hline 29 & 25.997 & Spiro[4.5]decan-6-one & 76 & 0.5935 \\
\hline 30 & 41.886 & MDMA methylene homolog & 43 & 0.5678 \\
\hline 31 & 25.368 & 3-Buten-2-ol, 2-methyl-4-(1,3,3-trimethyl-7-oxabicyclo[4.1.0] hept-2-yl)- & 43 & 0.5674 \\
\hline 32 & 9.242 & Cycloserine & 39 & 0.5460 \\
\hline 33 & 24.555 & 4-Piperidinamine, N,1-dimethyl- & 41 & 0.5387 \\
\hline 34 & 24.893 & Silane, dimethyldi-2-propenyl- & 43 & 0.5337 \\
\hline 35 & 51.816 & 2-Ethylacridine & 38 & 0.5263 \\
\hline 36 & 18.133 & 3-Bromo-1,2-propanediol & 43 & 0.5166 \\
\hline 37 & 24.959 & Guanidineacetic acid & 32 & 0.5133 \\
\hline 38 & 23.659 & Adenosine, 4'-de(hydroxymethyl)-4'-[N-ethylaminoformyl]- & 43 & 0.4704 \\
\hline 39 & 23.279 & Bicyclo[2.2.1] heptan-2-one, 4,7,7-trimethyl-, semicarbazone & 89 & 0.4526 \\
\hline 40 & 21.682 & 2-Cyclopenten-1-one, 4-hydroxy-3-methyl-2-(2-propenyl)- & 40 & 0.4506 \\
\hline 41 & 28.983 & Methanesulfonamide, $\mathrm{N}, \mathrm{N}$-dimethyl- & 43 & 0.4307 \\
\hline
\end{tabular}


Table 1 Active compounds present in the leaves oil extract of A. wilkesiana using GC-MS analysis (Continued)

\begin{tabular}{|c|c|c|c|c|}
\hline SN & Retention time (min) & Compound name/hit name & $\begin{array}{l}\text { Quality ion (relative } \\
\text { intensity, \%) }\end{array}$ & $\begin{array}{l}\text { Percentage } \\
\text { total of all } \\
\text { compound (\% total) }\end{array}$ \\
\hline 42 & 21.451 & Acetonitrile, 2-(2H-tetrazol-2-yl)- & 55 & 0.4223 \\
\hline 43 & 22.395 & Folic Acid & 46 & 0.3989 \\
\hline 44 & 22.282 & $\begin{array}{l}\text { Glucopyranuronamide, 1-(4-amino-2-oxo-1 (2H)-pyrimidinyl)-1, } \\
\text { 4-dideoxy-4-(D-2-(2-(methylamino)acetamido)hydracrylamido)-, beta.-D- }\end{array}$ & 47 & 0.3885 \\
\hline 45 & 25.861 & trans-5-Methyl-2-isopropyl-2-hexen-1-al & 35 & 0.3883 \\
\hline 46 & 22.543 & Diglycolamine & 47 & 0.3645 \\
\hline 47 & 14.121 & 2-Heptanamine, 5-methyl- & 42 & 0.3536 \\
\hline 48 & 31.855 & 9-Octadecenamide, (Z)- & 98 & 0.3378 \\
\hline 49 & 23.516 & Adrenalone & 50 & 0.3373 \\
\hline 50 & 12.043 & 1-Pentanol, 4-amino- & 47 & 0.3343 \\
\hline 51 & 5.479 & 2(3H)-Furanone, dihydro-3-hydroxy-4,4-dimethyl-, (.+/-.)- & 22 & 0.3273 \\
\hline 52 & 30.110 & Octadecanoic acid, 17-methyl-, methyl ester & 98 & 0.3222 \\
\hline 53 & 28.259 & 1H-Pyrazole, 4,5-dihydro-3-phenyl- & 64 & 0.3211 \\
\hline 54 & 26.810 & Guanidine, N,N,N',N'-tetramethyl- & 35 & 0.3158 \\
\hline 55 & 33.695 & 1-[.alpha.-(1-Adamantyl)benzylidene]thiosemicarbazide & 43 & 0.3039 \\
\hline 56 & 35.939 & $\begin{array}{l}\text { 1-Methylene-2b-hydroxymethyl-3,3-dimethyl-4b-(3-methylbut-2-enyl)- } \\
\text { cyclohexane }\end{array}$ & 47 & 0.2937 \\
\hline 57 & 12.667 & 2-Formylhistamine & 39 & 0.2854 \\
\hline 58 & 27.707 & Arginine & 38 & 0.2422 \\
\hline 59 & 17.712 &.$+/-.-$ Tetrahydro-3-furanmethanol & 28 & 0.2412 \\
\hline 60 & 43.631 & Ethyl 2-((diethoxyphosphoryl)oxy)-3,3,3-trifluoropropanoate & 9 & 0.2323 \\
\hline 61 & 9.426 & Pent-3-enylamine & 12 & 0.2318 \\
\hline 62 & 26.520 & 3,3'-Bis(1,2,4-oxadiazolyl)-5,5'-diamine & 50 & 0.2266 \\
\hline 63 & 27.161 & Imidazole, 2-amino-5-[(2-carboxy)vinyl]- & 38 & 0.2126 \\
\hline 64 & 29.737 & Linoleic acid ethyl ester & 99 & 0.2114 \\
\hline 65 & 11.569 & Methylpent-4-enylamine & 37 & 0.2079 \\
\hline 66 & 43.744 & $\begin{array}{l}\text { 1H-Indole-2-carboxylic acid, 6-(4-ethoxyphenyl)-3-methyl-4-oxo-4, } \\
\text { 5,6,7-tetrahydro-, isopropyl ester }\end{array}$ & 27 & 0.2068 \\
\hline 67 & 17.824 & N-Methylallylamine & 47 & 0.2064 \\
\hline 68 & 15.723 & Tetrahydro-4H-pyran-4-ol & 39 & 0.1836 \\
\hline 69 & 5.960 & 1,2-Propanediol, 3-chloro- & 47 & 0.1744 \\
\hline 70 & 13.563 & Ethyl oxamate & 33 & 0.1702 \\
\hline 71 & 34.146 & 4-Fluorohistamine & 43 & 0.1625 \\
\hline 72 & 13.177 & N-Methyl-N-[2-cyanoethyl]-2-mercapto propylamine & 47 & 0.1552 \\
\hline 73 & 20.383 & 1,2,3,4-Butanetetrol, [S-( $\left.\left.R^{*}, R^{*}\right)\right]-$ & 5 & 0.1533 \\
\hline 74 & 22.608 & Carvone oxide, cis- & 27 & 0.1501 \\
\hline 75 & 42.551 & Cefaclor & 4 & 0.1489 \\
\hline 76 & 18.311 & N-Methoxy-1-ribofuranosyl-4-imidazolecarboxylic amide & 38 & 0.1469 \\
\hline 77 & 6.043 & Ethyl hydrogen oxalate & 38 & 0.1467 \\
\hline 78 & 5.888 & Xylitol & 42 & 0.1399 \\
\hline 79 & 3.437 & 3-Butyn-1-ol & 9 & 0.1364 \\
\hline 80 & 8.114 & Bicyclo[3.1.0]hexan-3-one & 47 & 0.1361 \\
\hline 81 & 5.010 & Topotecan & 33 & 0.1228 \\
\hline 82 & 10.934 & 1-Dodecanamine & 28 & 0.1198 \\
\hline
\end{tabular}


Table 1 Active compounds present in the leaves oil extract of A. wilkesiana using GC-MS analysis (Continued)

\begin{tabular}{|c|c|c|c|c|}
\hline SN & Retention time (min) & Compound name/hit name & $\begin{array}{l}\text { Quality ion (relative } \\
\text { intensity, \%) }\end{array}$ & $\begin{array}{l}\text { Percentage } \\
\text { total of all } \\
\text { compound (\% total) }\end{array}$ \\
\hline 83 & 4.470 & Acetamide, 2-amino- $N$-(1-methylethyl)- & 9 & 0.1101 \\
\hline 84 & 42.112 & N-(3-Methylbutyl)acetamide & 9 & 0.1087 \\
\hline 85 & 41.132 & Cyclobutanol & 9 & 0.1030 \\
\hline 86 & 29.950 & Butanamide & 53 & 0.1015 \\
\hline 87 & 10.530 & Ethylene oxide & 5 & 0.0856 \\
\hline 88 & 4.880 & Silane, methyl- & 25 & 0.0818 \\
\hline 89 & 4.595 & 2-Butynone, 1-acetyl-4-[1-piperidyl]- & 35 & 0.0796 \\
\hline 90 & 29.517 & dl-Phenylephrine & 50 & 0.0731 \\
\hline 91 & 7.420 & Glycyl-dl-alanine & 9 & 0.0719 \\
\hline 92 & 8.589 & 1-Propanol, 2-amino-, (.+/-.)- & 28 & 0.0718 \\
\hline 93 & 4.725 & Dimethyl-(6-methyl-2-thioxo-[1,3,2]oxathiaphosphinan-2-yl)-amine & 42 & 0.0704 \\
\hline 94 & 33.310 & azetidine, 1-methyl-3,3-dipentyl- & 33 & 0.0670 \\
\hline 95 & 5.758 & L-Arabinitol & 59 & 0.0663 \\
\hline 96 & 31.612 & 2,4-Dimethylamphetamine & 59 & 0.0631 \\
\hline 97 & 27.321 & 2-Amino-1-(o-methoxyphenyl)propane & 37 & 0.0606 \\
\hline 98 & 31.001 & 2-Oxo-3-methyl-cis-perhydro-1,3-benzoxazine & 37 & 0.0562 \\
\hline 99 & 32.342 & 5-Aminoisoxazole & 9 & 0.0550 \\
\hline 100 & 5.164 & 3-Ethoxy-1,2-propanediol & 40 & 0.0525 \\
\hline 101 & 29.446 & Propanamide, 3-(3,4-dimethylphenylsulfonyl)- & 32 & 0.0515 \\
\hline 102 & 41.435 & 1-Octadecanamine, $\mathrm{N}$-methyl- & 9 & 0.0482 \\
\hline 103 & 37.868 & 1-(5-Bicyclo[2.2.1]heptyl)ethylamine & 17 & 0.0374 \\
\hline 104 & 9.729 & dl-Alanine & 9 & 0.0334 \\
\hline 105 & 3.229 & 2-(Oxan-3-yl)ethanamine & 38 & 0.0329 \\
\hline 106 & 41.031 & 4,6-dimethyl-2-(propan-2-yl)-1,3,5-dithiazinane & 5 & 0.0329 \\
\hline 107 & 35.387 & Benzaldehyde, 2-nitro-, diaminomethylidenhydrazone & 25 & 0.0319 \\
\hline 108 & 4.126 & 2-Hexynoic acid & 12 & 0.0309 \\
\hline 109 & 30.787 & Phenethylamine, p..alpha.-dimethyl- & 32 & 0.0297 \\
\hline 110 & 4.173 & Sulfurous acid, diethyl ester & 9 & 0.0293 \\
\hline 111 & 39.073 & 4,6-dimethyl-2-propyl-1,3,5-dithiazinane & 9 & 0.0290 \\
\hline 112 & 41.530 & Propan-1-one, 2-amino-1-piperidin-1-yl- & 9 & 0.0251 \\
\hline 113 & 38.639 & S-[Tri-t-butoxysilyl]-2-mercaptoethylamine & 9 & 0.0250 \\
\hline
\end{tabular}

of the oil extract. Similar result was obtained by Kolawole et al. (2014) research in which SOD in C. maculatus exposed to different dosages of some botanical insecticides was first increased and decreased with further increase in concentration of the biopesticides. Aslanturk, Kalender, Uzunhisarcikli, and Kalender (2011), Gupta et al. (2010), and Wu et al. (2011) also reported decrease in SOD activity in mid-gut tissues of Lymantria dispar exposed to methidathion, an organophosphate insecticide.

The generation of SOD activity leads to conversion of superoxide radicals to less $\mathrm{H}_{2} \mathrm{O}_{2}$ which in turn induces CAT activity that perfectly reduces accumulation of
$\mathrm{H}_{2} \mathrm{O}_{2}$ to water (Aslanturk et al., 2011; Kaur, Sohal, Arora, Kaur, \& Kaur, 2014; Łukasik, Goławska, \& Wójcicka, 2009). Aslanturk et al. (2011) opined that increase in activity of SOD would lead to increased $\mathrm{H}_{2} \mathrm{O}_{2}$ thus increase the activity of CAT. The increase in CAT activity in C. maculatus stressed with 0.2 and $0.4 \mathrm{ml}$ of $A$. wilkesiana oil extract could be due to increased SOD activities at these dosages. Thus, this must have caused conversion of hydrogen peroxide to water and prevention of oxidative damage. Hence, it lowers the risk of hydroxyl radicals' formation through Fenton reaction (Fridovich, 1999; Kolawole et al., 2014). This finding supported the reports of Orr and Sohal (1994) that 


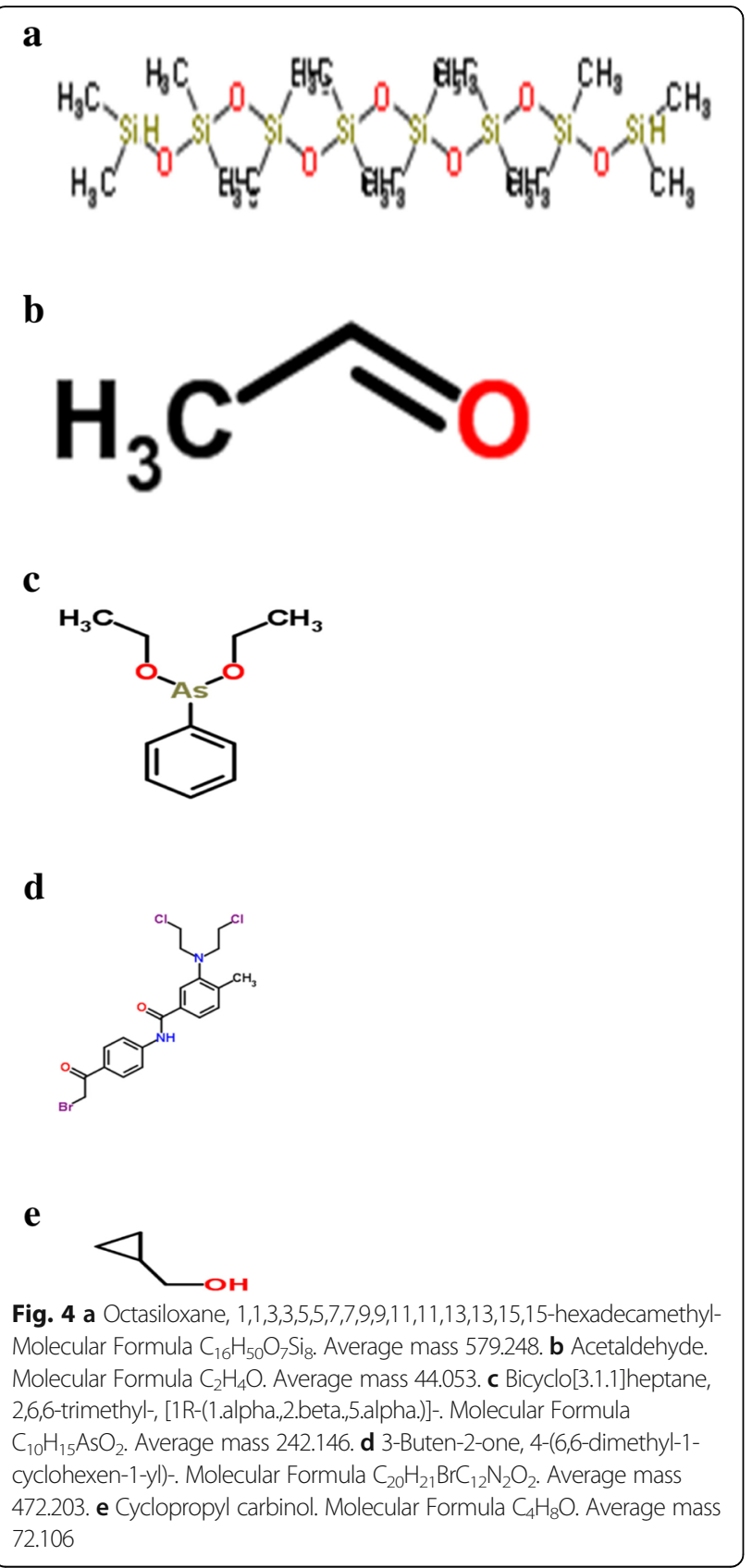

suggested that CAT protects cells against oxidative stress and extends lifespan of insects. However, it was noted in this work that further increase in the dosage of $A$. wilkesiana leaves oil extract significantly reduced the activity of CAT. This could be due to inability of the enzyme to catalyze the accumulation of $\mathrm{H}_{2} \mathrm{O}_{2}$ that resulted from SOD activity. This result acquiesced with the findings of Kaur et al. (2014) and Łukasik (2007). The result of this work revealed that activity of GPx increased at lower dosages of the oil extract and significantly reduced at higher dosages. The increase in the GPx activities could be associated to the increased CAT activity because it is when CAT is saturated that GPx, the second line of defense regulated by Selenium availability, is activated (Ali, 2012; Duntas, 2012). GPx catalyzes the glutathionedependent reduction of lipid peroxides and hydrogen peroxide for detoxification at the membrane level into less reactive species by using GSH as substrate (Ali, 2012; Sankar et al., 2012). Thus, it prevents the progressive formation of free radicals and protects the cell against oxidative stress and lipid peroxidation (Sankar et al., 2012). Hence, the decrease in the activity of GPx indicates that there could be accumulation of lipid peroxides and hydrogen peroxides. This result agreed with the findings of Aslanturk et al. (2011) in which methidathion caused an increase in oxidative stress of $L$. dispar larvae.

Acetylcholine esterase (AChE) is an important neurotransmitter enzyme that degrades the molecule acetylcholine (ACh) to produce choline and acetate group. It is mainly found in the neuromuscular junctions and cholinergic synapses of the central nervous system where it terminates synaptic transmission (Kim et al., 2010; Purves et al., 2008). Thus, the choline produced by activity of $\mathrm{AChE}$ is recycled by being transported back to the nerve terminals for the synthesis of new Ach (Herholz, Weisenbach, Hilker, \& Heiss, 2006; Kim et al., 2010). In this work, the activity of AChE significantly reduced when compared to the control and almost got inhibited by $1.0 \mathrm{ml}$ of $A$. wilkesiana oil extract. Thus, this implies that the activity of the enzyme had been significantly inhibited by the oil extract and may have caused increase in the concentration of ACh that could lead to buildup of the neurotransmitter at nerve synapse and neuromuscular junctions (Fukuto, 1990; Rajashekar, Raghavendra, \& Bakthavatsalam, 2014). The inhibitory effect of the oil extract on the activity of this enzyme can also be attributed to the active compounds it contained because active compounds of botanicals have been reported to have broad impact across the nervous system which is attenuated by modified acetyl choline and acetate function as suggested by Rajashekar et al. (2014). The result obtained from this study was in accordance with the results of Begum, Sharma, and Pandey (2010), Breuer, Hoste, De Loof, and Naqvi (2003), Ghoneim, Hamadah, and El-Hela (2012), Khan et al. (2003), Kim et al. (2008), Olmedo et al. (2015), and Prakash (2015) in which botanical-based insecticides were found to cause inhibition of AChE activities in insects.

In insects, CarEST is involved in many important physiological processes and plays an imperative role in the detoxification of insecticides to less toxic metabolites (Jones \& Brancoft, 1986; Lassiter, Apperson, \& Roe, 1995; Mukanganyama, Figueroa, Hasler, \& Niemeyer, 2003; Shanmugavelu, Baytan, Chesnut, \& Bonning, 2000; Tarigan, Dadang, \& Harahap, 2016; Wheelock, Shan, \& Ottea, 2005). Thus, it is used as 
one of the most reliable biomarkers to assess the impact of insecticides on range of insects (Fourcy, Jumel, Heydorff, \& Lagadic, 2002; Koodalingam, Mullainadhan, \& Arumugam, 2011; Smirle, Zurowski, Lowery, \& Foottit, 2010; Wheelock et al., 2005). In this research, the activity of this enzyme was found to increase at lower dosages $(0.2$ and $0.4 \mathrm{ml}$ of $2 \%$ concentration of the oil extract) while it drastically reduced with higher dosages of the oil extract, reflecting that the enzyme activity was dose dependent. The dose-dependent activity of CarEST in the larvae of Choristoneura rosaceana exposed to neem oil (Smirle, Lowery, \& Zurowski, 1996) while Ortego, López-Olguín, Ruiz, and Castañera (1999) reported the reduction in CarEST activity in the larvae of Leptinotarsa decemlineata exposed to limnoid. This result also agreed with the findings of Caballero, Lopez-Olguin, Ruiz, Ortego, and Castanera (2008), Koodalingam et al. (2011), Malahat, Jalal, and Alireza (2015), and Nathan et al. (2008). In contrast, Koodalingam et al. (2011) reported that the activity of CarEST in pupa of Aedes aegypti was not affected by the extract of Sapindus emarginatus. This variation could be due to the stages of insect used as reported by Koodalingam et al. (2011).

GST is a multifunctional enzyme responsible for the detoxification of many toxic substances in insects. It also catalyzes the conjugation of reduced glutathione and plays a vital role in detoxification of insecticides, thus rendering the less toxic (Rufingier, Pasteur, Lagnel, Martin, \& Navajas, 1999; Tarigan et al., 2016). In this study, GST activity in adult $C$. maculatus was greatly reduced at higher dosages of the oil extract, thus the activity of the enzyme was dosage dependent. This result was supported by report of Van, Haubruge, Lognay, and Francis (2001) that stated that botanical extracts induce GST activity. War, Paulraj, Ignacimuthu, and Sharma (2013) reported that botanical extract have the ability to reduce total protein in insects, thus toxicity of plant extract is characterized by its ability to reduce the amount of total protein insects (Nath, Kalaivan, \& Chung, 1997; Tarigan et al., 2016). Terrie (1984) reported that GST is a type of enzyme made of $85 \%$ protein and plays a critical role in the detoxification of toxic substances that enter and leave the body of insects. The decrease in the activity of GST at higher dosages of the plant oil extract could be that the protein content of the insect had been reduced. Similar result was reported by Ebadollahi, Roya, Jalal, Parisa, and Rahim (2013) in which botanical extract was found to cause low protein content in the body of Tribolium castaneum and in turn cause inhibition of GST. Furthermore, it was noted that most of the compounds found in the oil extract of $A$. wilkesiana oil extract were alkaloids. Thus, the effect of the oil extract of the plant could be due to these active compounds according to Yang, Zhao, Zhu, Fang, and Xia (2006) reports.

\section{Conclusion}

In conclusion, the oil extract of $A$. wilkesiana leaves appeared potent against the activities of all the antioxidant enzymes (SOD, CAT, and GPx), the esterases (AChE and CarEST), and the GST tested in this work. Thus, it means that oil extract of the plant has a multiple mode of action and it has affected all the enzymes evaluated. However, its inhibitory effects were more pronounced on the AChE activity as it almost inhibits the activity of enzyme. Based on these findings, oil extract of $A$. wilkesiana could be suggested as potential biopesticide for the control of C. maculatus infestation. More so, many of the compounds found in it are insecticidal in nature.

\section{Abbreviations \\ AChE: Acetylcholine esterase; CarEST: Carboxylesterase; CAT: Catalase; GPx: Glutathione peroxidase; GST: Glutathione transferase; SOD: Superoxide} dismutase

\section{Acknowledgements}

We acknowledge the technologists in the postgraduate research laboratory of the Department of Crop, Soil , and Pest Management for their assistance during the period when this research was being carried out.

\section{Authors' contributions}

The first and second authors designed the research while third and fourth authors joined them in carrying out the bench work. Second author carried out statistical analysis of data obtained and wrote the manuscript while the fifth author proof read the manuscript and make necessary adjustments. All authors read and approved the final manuscript.

\section{Funding}

There was no external funding for this research. The research was selffunded.

Availability of data and materials

Sharing of data is not applicable to this manuscript because no datasets were generated during this study.

Ethics approval and consent to participate

Not applicable.

\section{Consent for publication}

Not applicable.

\section{Competing interests}

The authors declare that they have no competing interests.

\section{Author details}

${ }^{1}$ Department of Crop, Soil and Pest Management, Federal University of Technology Akure, P.M.B 704, Akure, Nigeria. ${ }^{2}$ Department of Biology, Federal University of Technology Akure, Akure, Nigeria. ${ }^{3}$ Department of Biochemistry, Federal University of Technology Akure, Akure, Nigeria.

Received: 23 April 2019 Accepted: 31 May 2019

Published online: 01 July 2019

\section{References}

Abd-Elhady, H. K. (2012). Insecticidal activity and chemical composition of essential oil from Artemisia judaica I. against Callosobruchus maculatus (f.) (Coleoptera: Bruchidae). Journal of Plant Protection Research, 52(3), 347-352. 
Abdul Jaleel, C., Lakshmanan, G. M. A., Gomathinayagam, M., \& Panneerselvam, R. (2008). Triadimefon induced salt stress tolerance in Withania somnifera and its relationship to antioxidant defense system. South African Journal of Botany, 74, 126-132.

Aebi, H. (1984). Catalase, in vitro. Methods in Enzymology, 105, 121-126.

Ali, Z. Y. (2012). Neurotoxic effect of lambda-Cyhalothrin, a synthetic pyrethroid pesticide: Involvement of oxidative stress and protective role of antioxidant mixture. New York Science Journal, 5(9), 93-103.

Ashamo, M. O., Odeyemi, O. O., \& Ogungbite, O. C. (2013). Protection of cowpea, Vigna unguiculata L. (Walp.) with Newbouldia laevis (Seem.) extracts against infestation by Callosobruchus maculatus (Fabricius). Archives of Phytopathology and Plant Protection, 46(11), 1295-1306. https://doi.org/10.1080/03235408.2013.765136.

Aslanturk, A., Kalender, S., Uzunhisarcikli, M., \& Kalender, Y. (2011). Effects of Methidathion on antioxidant enzyme activities and malondialdehyde level in midgut tissues of Lymantria dispar (Lepidoptera) larvae. Journal of the Entomological Research Society, 13(3), 27-38.

Bamidele, O., Ajele, J., Kolawole, A., \& Akinkuolere, O. (2013). Changes in the tissue antioxidant enzyme activities of palm weevil (Rynchophorous phoenicis) larva by the action of 2, 2-dichlorovinyl dimethyl phosphate. African Journal of Biochemistry Research, 7(7), 128-137.

Beauchamp, C., \& Fridovich, I. (1971). Improve assays and an assay applicable to acrylamide gels. Analytical Biochemistry, 44, 276-287.

Begum, N., Shaarma, B., \& Pandey, R. S. (2013). Caloptropis procera and Annona squamosa: Potential alternatives to chemical pesticides. British Journal of Applied Science \& Technology, 3(2), 254-267. https://doi.org/10.9734/BJAST/2014/2205.

Begum, N., Sharma, B., \& Pandey, R. S. (2010). Toxicity potential and anti AchE activity of some plant extracts in Musca Domestica. Journal of Biofertilizers \& Biopesticides, 2, 108-113.

Bocquene, G., \& Galgani, F. (1998). Biological effects of contaminants: Cholinesterase inhibition by organophosphate and carbamate compounds. ICES Techniques in Marine Environmental Sciences, 22, 1-12.

Bradford, M. M. (1976). A rapid and sensitive method for the quantitation of microgram quantities of protein utilizing the principle of protein-dye binding. Analytical Biochemistry, 72, 248-254.

Breuer, M., Hoste, B., De Loof, A., \& Naqvi, S. N. H. (2003). Effect of Melia azedarach extract on the activity of NADPH-cytochrome $\mathrm{c}$ reductase and cholinesterase in insects. Pesticide Biochemistry and Physiology, 76, 99-103.

Buyukguzel, K. (2006). Malathion induced oxidative stress in parasitoid wasp: Effect on adult emergence, longevity, fecundity, oxidative and antioxidative response of the Pimpla turionellae. Journal of Economic Entomology, 100, 1533-1541.

Caballero, C., Lopez-Olguin, J., Ruiz, M., Ortego, F., \& Castanera, P. (2008). Antifeedant activity and effect of terpinoids on detoxification enzymes of the beet armyworm, Spodoptera exigua (Hubner). Spanish Journal of Agricultural Research, 6, 177-184.

Duntas, L. H. (2012). The evolving role of selenium in the treatment of Graves' disease and Ophthalmopathy. Journal of Thyroid Research. https://doi.org/10. 1155/2012/736161.

Ebadollahi, A., Roya, K., Jalal, J. S., Parisa, H., \& Rahim, M. A. (2013). Toxicity and physiological effects of essential oil from Agastache foeniculum (Pursh) Kuntze against Tribolium castaneum Herbst (Coleoptera: Tenebrionidae) larvae. Annual Research \& Review in Biology, 3(4), 649-658.

Ellman, G. L., Courtney, D., Andres, V., \& Featherstone, R. M. (1961). A new and rapid colorimetric determination of acetylcholinesterase activity. Biochemical Pharmacology, 7, 88-95.

Forim, M. R., Da-silva, M. F. G. F., \& Fernandes, J. B. (2012). Secondary metabolism as a measurement of efficacy of botanical extracts: The use of Azadirachta indica (neem) as a model. In F. Perveen (Ed.), Insecticides-advances in integrated pest management, (pp. 367-390) ISBN:987-953-307-780-2.

Fourcy, D., Jumel, A., Heydorff, M., \& Lagadic, L. (2002). Esterases as biomarkers in Nereis (Herdiste) diversicolor exposed to temephos and Bacillus thuringiensis var. israelensis used for mosquito control in coastal wetlands of Morbihan (Brittany, France). Marine Environmental Research, 54, 755-759.

Fridovich, I. (1999). Fundamental aspects of reactive oxygen species, or what's the matter with oxygen. Annals of the New York Academy of Sciences, 893 $13-18$.

Fukuto, R. T. (1990). Mechanism of action of organophosphorus and carbamate insecticides. Environmental Health Perspectives, 87, 245-254.

Ghoneim, K. E., Hamadah, S. K., \& El-Hela, A. A. (2012). Acetylcholinesterase activity in the desert locust Schistocerca gregaria (Acrididae) (Forsk.) as a response to the action of the wild herb Fagonia bruquieri DC. (Zygophyllaceae) extracts. Journal of the Entomological Research Society, 14(2), 87-97.
Goławska, S., \& Łukasik, I. (2012). Antifeedant activity of luteolin and genistein against the pea aphid, Acyrthosiphon pisum. Journal of Pest Science, 85, 443-450.

Goławska, S., Łukasik, l., Goławski, A., Kapusta, I., \& Janda, B. (2010). Alfalfa (Medicago sativa L.) apigenin glycosides and their effect on the pea aphid (Acyrthosiphon pisum). Polish Journal of Environmental Studies, 19, 913-920.

Guerrero, A., \& Rosell, G. (2005). Biorational approaches for insect control by enzymatic inhibition. Current Medicinal Chemistry, 12, 461-469.

Gupta, S. C., Mishra, M., Sharma, A., Deepak, B. T. G. R., Kumar, R., Mishra, R. K., \& Chowdhuri, D. K. (2010). Chlorpyrifos induces apoptosis and DNA damage in Drosophila through generation of reactive oxygen species. Ecotoxicology and Environmental Safety, 73(6), 1415-1423.

Habig, W. H., Pabst, M. J., \& Jokoby, W. B. (1974). Glutathione-S-transferase: The first enzymatic step in mercapturic acid formation. The Journal of Biological Chemistry, 249, 7130-7139.

Henry, W. L., Chao-Lin, K., Wen-Hui, Y., Chia-Hsien, L., \& Hong-Zin, L. (2006). Antioxidant enzymes activity involvement in luteolin-induced human lung squamous carcinoma $\mathrm{CH} 27$ cell apoptosis. European Journal of Pharmacology, $534,2123-2130$.

Herholz, K., Weisenbach, S., Hilker, R., \& Heiss, W. (2006). Measuring cortical acetylcholine esterase activity by PET in dementia. Clinical Correlates Neuro $R X, 3,410$.

Isman, M. B. (2000). Plant essential oils for pest and disease management. Crop Protection, 19(8-10), 603-608.

Isman, M. B. (2006). Botanical insecticides, deterrents, and repellents in modern agriculture and an increasingly regulated world. Annual Review of Entomology, 51, 45-66.

Isman, M. B., \& Grieneisen, M. L. (2014). Botanical insecticide research: Many publications, limited useful data. Trends in Plant Science, 19(3), 140-145.

Jaya, P. S., Prakash, B., \& Dubey, N. K. (2012). Insecticidal activity of Ageratum conyzoides L., Coleus aromaticus Benth. and Hyptis suaveolens (L.) Poit essential oils as fumigant against storage grain insect Tribolium castaneum Herbst. Journal of Food Science and Technology. https://doi.org/10.1007/s13197-012-0698-8.

John, S., Kale, M., Rathore, N., \& Bhatnagar, D. (2001). Protective effect of vitamin E in dimethoate and malathion induced oxidative stress in rat erythrocytes. The Journal of Nutritional Biochemistry, 12, 500-504.

Jones, B. R., \& Brancoft, H. R. (1986). Distribution and probable physiological role of esterases in reproductive, digestive and fat-body tissue of adult cotton boll weevil, Anthonomus grandis. Biochemical Genetics, 24, 499-508.

Kaur, A., Sohal, S. K., Arora, S., Kaur, H., \& Kaur, A. P. (2014). Effect of plant extracts on biochemistry of Bactrocera cucurbitae (Coquillett). Journal of Entomology and Zoology Studies, 2(3), 86-92.

Kedia, A., Prakash, B., Mishra, P. K., Singh, P., \& Dubey, N. K. (2013). Botanicals as eco-friendly biorational alternatives of synthetic pesticides against Callosobruchus spp. (Coleoptera: Bruchidae) - a review. Journal of Food Science and Technology. https://doi.org/10.1007/s13197-013-1167-8.

Khan, M. Z., Naqvi, S. N. H., Khan, M. F., Tabassum, R., Ahmad, I., \& Fatina, F. (2003). Induced effect of neem based formulation, Biosal, on cholinesterase activity, and protein content in kidney and liver of Calotes versicolor Daudin. Journal of Experimental Zoology, (India), 6, 175-179.

Kim, D., Lee, S., Hong, J., Lillehoj, H., Park, H., Rhie, S., \& Lee, G. (2010). The butanol fraction of Eclipta prostrata (Linn) increases the formation of brain acetylcholine and decreases oxidative stress in the brain and serum of cesarean-derived rats. Nutrition Research, 30, 579-584.

Kim, D. I., Lee, S. H., Choi, J. H., Lillehoj, H. S., Yu, M. H., \& Lee, G. S. (2008). The butanol fraction of Eclipta prostrata (Linn) effectively reduces serum lipid levels and improves antioxidant activities in CD rats. Nutrition Research, 28, 550-554.

Kolawole, A. O., Olajuyigbe, F. M., Ajele, J. O., \& Adedire, C. O. (2014). Activity of the antioxidant defense system in a typical bioinsecticide-and synthetic insecticide-treated cowpea storage beetle Callosobrochus maculatus F. (Coleoptera: Chrysomelidae). International Journal of Insect Science, 6, 99-108. https://doi.org/10.4137/IJIS.S19434.

Koodalingam, A., Mullainadhan, P., \& Arumugam, M. (2011). Effects of extract of soapnut Sapindus emarginatus on esterases and phosphatases of the vector mosquito, Aedes aegypti (Diptera: Culicidae). Acta Tropica, 118(2011), 27-36.

Lassiter, M. T., Apperson, C. S., \& Roe, R. M. (1995). Juvenile hormone metabolism during the fourth stadium and pupal stage of the southern house mosquito, Culex quinquefasciatus Say. Journal of Insect Physiology, 41, 869-876.

Łukasik, I. (2007). Changes in activity of superoxide dismutase and catalase within cereal aphids in response to plant o-dihydroxyphenols. Journal of Applied Entomology, 13, 209-214. 
Łukasik, I., Goławska, S., \& Wójcicka, A. (2009). Antioxidant defense mechanisms of cereal aphids based on ascorbate and ascorbate peroxidase. Biologia, 64, 994-998.

Malahat, M. M., Jalal, J. S., \& Alireza, A. (2015). Effect of Artemisia annua L. essential oil on toxicity,enzyme activities, and energy reserves of cotton bollworm Helicoverpa armigera (Hübner) (Lepidoptera: Noctuidae). Journal of Plant Protection Research, 55(4), 371-377.

Martins, C. H. Z., Freire, M. G. M., Parra, J. R. P., \& Macedo, M. L. R. (2012) Physiological and biochemical effects of an aqueous extract of Koelreuteria paniculata (Laxm.) seeds on Anticarsia gemmatalis (Huebner) (Lepidoptera: Noctuidae). SOAJ Entomology Studies, 1, 81-93.

Mukanganyama, S., Figueroa, C. C., Hasler, J. A., \& Niemeyer, H. M. (2003). Effects of DIMBOA on detoxification enzymes of the aphid, Rhopalosiphum padi (Homoptera: Aphididae). Journal of Insect Physiology, 49, 223-229.

Nath, S. S., Kalaivan, K., \& Chung, P. G. (1997). The effects of azadirachtin and nucleopolyhedrovirus on midgut enzymatic profile of Spodoptera litura Fab. (Lepidoptera: Noctuidae). Pesticide Biochemistry \& Physiology, 83(1), 46-57.

Nathan, S. S., Choi, M. Y., Seo, H. Y., Paik, C. H., Kalaivani, K., \& Kim, J. D. (2008). Effect of azadirachtin on acetylcholinesterase (AchE) activity and histology of the brown planthopper Nilaparvata lugens (Stal). Ecotoxicology and Environmental Safety, 70, 244-250.

Ogungbite, O. C. (2015). Entomopoison efficacy of fume of different parts of Newbouldia laevis against Callosobruchus maculatus in storage. International Journal of Research Studies in Microbiology and Biotechnology, 1(1), 6-14.

Oguntuase, S. O. (2018). Insecticidal potentials of oil extract of Acalypha wilkesiana against Callosobruchus maculatus infesting stored cowpea, A thesis dissertation submitted to the Department of Crop, Soil and Pest Management, Federal University of Technology Akure (p. 120).

Olawale, O., Ikechukwu, N. E., Grace, T. O., \& Chidiebere, E. U. (2008). Oxidative stress and superoxide dismutase activity in brain of rats fed with diet containing permethrin. Biokemistri, 20, 93-98.

Olmedo, R., Herrera, J. M., Lucini, E. I., Zunino, M. P., Pizzolitto, R. P., Dambolena, J. S., \& Zygadlo, J. A. (2015). Essential oil of Tagetes filifolia against the flour beetle Tribolium castaneum and its relation to acetylcholinesterase activity and lipid peroxidation. Agriscientia, 32(2), 113-121.

Oni, M. O. (2014). Entomotoxic efficacy of cayenne pepper, sweet pepper and long cayenne pepper oil extracts against Sitophilus zeamais infesting maize grain. Molecular Entomology, 5(5), 37.

Oni, M. O., Ogungbite, O. C., \& Ofuya, T. I. (2018). Biotoxic efficacy of different fractions of Acalypha godseffiana oil extract against Callosobruchus maculatus infesting stored cowpea. Medicinal Plant Research, 8(2), 8-13. https://doi.org/ 10.5376/mpr.2018.08.0002.

Orr, W. C., \& Sohal, R. S. (1994). Extension of life-span by overexpression of superoxide dismutase and catalase in Drosophila melanogaster. Science, 263, $1128-1130$

Ortego, F., López-Olguín, J., Ruiz, M., \& Castañera, P. (1999). Effects of toxic and deterrent terpenoids on digestive protease and detoxification enzyme activities of Colorado potato beetle larvae. Pesticide Biochemistry \& Physiology, 63, 76-84.

Paglia, D. E., \& Valentine, W. N. (1967). Studies on the quantitative and qualitative characterization of erythrocytes glutathione peroxides. The Journal of Laboratory and Clinical Medicine, 70, 158-169.

Prakash, K. S. B. (2015). Toxicity and biochemical efficacy of chemically characterized Rosmarinus officinalis essential oil against Sitophilus oryzae and Oryzaephilus surinamensis. Industrial Crops and Products, 74, 817-823.

Purves, D., Augustine, G. J., Fitzpatrick, D., Hall, W. C., LaMantia, A. S., McNamara, J. O., et al. (2008). Neuroscience. Sunderland: Sinauer Associates.

Rajashekar, Y., Raghavendra, A., \& Bakthavatsalam, N. (2014). Acetylcholinesterase inhibition by biofumigant (Coumaran) from leaves of Lantana camara in stored grain and household insect pests. BioMed Research International. https://doi.org/10.1155/2014/187019.

Rattan, R. S., \& Sharma, A. (2011). Plant secondary metabolites in the sustainable diamondback moth (Plutella xylostella L.) management. Indian Journal of Fundamental and Applied Life Science, 1(3), 295-309.

Rufingier, C., Pasteur, N., Lagnel, J., Martin, C., \& Navajas, M. (1999). Mechanisms of insect resistance in the aphid, Nasonovia ribisnigri (Mosley) (Homoptera: Aphididae), from France. Insect Biochemistry and Molecular Biology, 29, 385-391.

Sankar, P., Telang, A. G., \& Manimaran, A. (2012). Protective effect of curcumin on cypermethrin-induced oxidative stress in Wistar rats. Experimental and Toxicologic Pathology, 64, 487-493.

Scott, I. M., Jensen, H., Scott, J. G., Isman, M. B., Arnason, J. T., \& Philogène, B. J. R. (2003). Botanical insecticides for controlling agricultural pests: Piperamides and the Colorado potato beetle Leptinotarsa decemlineata say (Coleoptera: Chrysomelidae). Archives of Insect Biochemistry and Physiology, 54, 212-225.

Shanmugavelu, M., Baytan, A. R., Chesnut, J. D., \& Bonning, B. C. (2000). A novel protein that binds juvenile hormone esterase in fat body tissues and pericardial cells of the tobacco horn worm Manduca sexta L. Journal of Biological Chemistry, 275, 1802-1806.

Shimomura, K., Koshino, H., Yajima, A., Matsumoto, N., Yajima, S., \& Ohsawa, K. (2010). A new sesquiterpenoid produced by female Callosobruchus rhodesianus (Pic): A possible component of the sex attractant pheromone. Tetrahedron Letters, 51, 6860-6862.

Sivakumar, C., Chandrasekaran, S., Vijayaraghavan, C., \& Selvaraj, S. (2010). Fumigant toxicity of essential oils against pulse beetle, Callosobrucrhus maculatus (F.) (Coleoptera: Bruchidae). Journal of Biopesticides, 3(1 Special Issue), 317-319.

Smirle, M. J., Lowery, T., \& Zurowski, C. L. (1996). Influence of neem oil on detoxification enzyme activity in the oblique-banded leaf roller, Choristoneura rosaceana. Pest. Biochemistry \& Physiology, 56, 220-230.

Smirle, M. J., Zurowski, C. L., Lowery, D. T., \& Foottit, R. G. (2010). Relationship of insecticide tolerance to esterase enzyme activity in Aphis pomi and Aphis spiraecola. Journal of Economic Entomology, 103, 374-378.

Tarigan, S., Dadang, I., \& Harahap, S. I. (2016). Toxicological and physiological effects of essential oils against Tribolium castaneum (Coleoptera: Tenebrionidae) and Callosobruchus maculatus (Coleoptera: Bruchidae). Journal of Biopesticides, 9(2), 135-147.

Terrie, L. C. (1984). Induction of detoxification enzymes in insects. Annual Review of Entomology, 29, 71-88.

Tripathi, P., \& Dubey, N. K. (2004). Exploitation of natural products as an alternative strategy to control postharvest fungal rotting of fruit and vegetables. Postharvest Biology and Technology, 32, 235-245.

Van Asperen, K. (1962). A study of housefly esterases by means of a sensitive colorimetric method. Journal of Insect Physiology, 8, 401-416.

Van, H. N., Haubruge, E., Lognay, G., \& Francis, F. (2001). Hoverfly glutathione -Stransferases and effect of Brassicaceae secondary metabolites. Pesticide Biochemistry and Physiology, 71, 170-177.

Wang, H., Wen, C., Chang, X., \& Duan, C. (2002). Some detoxication mechanisms of different wheat varieties under cadmium treatment. Acta Scientiae Circumstantiae, 22, 523-528.

War, A. R., Paulraj, M. G., Ignacimuthu, S., \& Sharma, H. C. (2013). Defensive responses in groundnut against chewing and sap-sucking insects. Journal of Plant Growth Regulation, 32(2), 259-272.

Wheelock, C. E., Shan, G., \& Ottea, J. (2005). Overview of carboxylesterase and their role in the metabolism of insecticides. Journal of Pest Science, 30, 75-83.

Wu, H., Liu, J., Zhang, R., Zhang, J., Guo, Y., \& Ma, E. (2011). Biochemical effects of acute phoxim administration on antioxidant system and acethylcholinesterase in Oxya chinensis (Thunberg) (Orthoptera: Acrididae). Pesticide Biochemistry \& Physiology, 100, 23-26.

Yang, Z., Zhao, B., Zhu, L., Fang, J., \& Xia, L. (2006). Inhibitory effects of alkaloids from Sophora alopecuroids on feeding, development and reproduction of Clostera anastomosis. (c) Higher Education Press and Springer-Verlag.

Zibaee, A. (2011). Botanical Insecticides and Their Effects on Insect Biochemistry and Immunity. In M. Stoytcheva (Ed.), Pesticides in the Modern World - Pests Control and Pesticides Exposure and Toxicity Assessment, (pp. 55-68). InTech.

Zibaee, A., \& Bandani, A. R. (2010). A study on the toxicity of the medicinal plant, Artemisia annua L. (AStracea) extracts the Sunn pest, Eurygaster integriceps Puton (Heteroptera: Scutelleridae). Journal of Plant Protection Research, 50, 48-54.

\section{Publisher's Note}

Springer Nature remains neutral with regard to jurisdictional claims in published maps and institutional affiliations. 